\title{
PENGEMBANGAN BAHAN AJAR IPS BERBASIS KONSTRUKTIVISTIK UNTUK SEKOLAH DASAR
}

\author{
Megayani Lestari \\ email: megayanil@yahoo.com \\ PGSD FIP Universitas Negeri Jakarta
}

Jl. Setiabudi No. 1 Kelurahan Setiabudi Jakarta Selatan

\begin{abstract}
Abstrak: Penelitian dan pengembangan bertujuan untuk menghasilkan produk berupa bahan ajar IPS untuk siswa kelas 5 Sekolah Dasar, dengan tema perjuangan para tokoh dalam melawan penjajah pada masa pendudukan Belanda dan Jepang. Penelitian ini menggunakan metode penelitian dan pengembangan dengan mengikuti model pengembangan Atwi Suparman, dilakukan pada bulan Oktober 2015 sampai Juni 2016. Jumlah siswa yang terlibat dalam penelitian sebanyak 43 siswa kelas 5 SDN Jati 03 Pagi Jakarta Timur. Penilaian produk dilakukan oleh penelaah ahli, kemudian diuji coba pada saat melakukan evaluasi formatif one to one, kelompok kecil, dan uji lapangan. Hasil uji coba menunjukkan, produk bahan ajar IPS berbasis konstruktivistik untuk siswa kelas V Sekolah Dasar memperoleh kriteria sangat baik.

Kata-kata Kunci: Bahan ajar, Kontruktivistik, Ilmu Pengetahuan Sosial
\end{abstract}

\section{DEVELOPING SOCIAL SCIENCE LEARNING MATERIALS BASED ON CONSTRUCTIVISM FOR ELEMENTARY SCHOOL}

\begin{abstract}
The purpose of this research is to produce the learning materials for Social Science Study at the fifth grade of elementary school students. The materials were focused on the theme of the Indonesian struggle against Dutch and Japanese colonialism. The learning materials were produced by applying the research and development model adopted by Atwi Suparman. This research, conducted as from October 2015 through 2016, involved 43 students of the fifth grade, in the State Primary School of Jati 03 Pag, i East Jakarta. For product evaluation, this research used expert review before trying out to-one-to-one, small group, and field test. The try out indicates, the learning materials developed for Social Science Study based on constructivism meets the criteria of "very good" at the fifth grade of Primary School.
\end{abstract}

Keywords: Learning Materials, Constructivism, Social Science

\section{PENDAHULUAN}

Pendidikan mengalami pertumbuhan yang sangat pesat dari masa ke masa, disertai perangkat pendidikan yang canggih. Pendidikan kini tidak hanya dalam dunia nyata saja, melainkan telah merambah ke dunia maya. Masyarakat dapat dengan mudah mengakses informasi melalui internet, tanpa perlu bertatap muka ataupun berkomunikasi secara langsung. Oleh sebab itu, perkembangan pendidikan yang telah maju, menuntut masyarakat untuk dapat mengembangkan diri dengan pengetahuan dan keterampilan sehingga tercapai masyarakat yang madani.

Dalam upaya mencapai terciptanya masyarakat yang madani tersebut, beberapa kebijakan telah dilakukan oleh pemerintah dalam bidang pendidikan, khususnya dalam bidang pembelajaran. Salah satunya melalui efektivitas pembelajaran yang terus dikembangkan. Mata pelajaran IPS perlu diberikan untuk mengembangkan potensi siswa agar mampu menghadapi tantangan hidup, serta tantangan global di masa mendatang. Pendidikan juga harus dapat mendorong siswa agar dapat memiliki pengetahuan, keterampilan, dan kepercayaan diri, serta mampu beradaptasi dengan lingkungan. Pendidikan yang dicita-citakan, adalah pendidikan yang mampu memberikan bekal hidup kepada siswa, tidak hanya terhenti pada penugasan materi saja.

Masalah yang terjadi dalam proses pembelajaran IPS di SD Negeri Jati 03 Pagi, Jakarta Timur yaitu banyak siswa yang tidak memperhatikan ketika 
pelajaran IPS berlangsung. Siswa sesekali bercanda dengan teman sebangkunya, atau berbincangbincang. Siswa terlihat bosan, mengingat ketika pelajaran IPS berlangsung guru menyampaikan materi melalui ceramah, kemudian siswa diminta untuk mencatat, dan mengerjakan soal latihan.

Menurut hasil wawancara dengan beberapa siswa kelas V SD Negeri Jati 03 Pagi yang tidak menyukai mata pelajaran IPS, rata-rata menyebutkan bahwa mata pelajaran IPS adalah mata pelajaran yang sulit karena materinya terlalu banyak. Menurut siswa, buku paket serta lembar kerja yang siswa miliki tidak menarik karena buku paket tersebut merupakan buku lama yang dipinjamkan oleh sekolah dari tahun ke tahun kepada siswa, dan terkadang sudah banyak coretan sehingga siswa malas membaca.

Berdasarkan hasil wawancara dengan guru kelas V SDN Jati 03 Pagi, kesulitan yang dihadapi dalam melaksanakan pembelajaran IPS dipengaruhi oleh beberapa faktor, di antaranya kesadaran diri siswa untuk belajar masih kurang sehingga mengakibatkan siswa menjadi tidak termotivasi untuk belajar. Selain itu, peneliti mengamati bahwa selama mengajar, guru jarang memakai media pembelajaran. Guru lebih suka mengajar menggunakan buku paket dan buku lembar kerja siswa, sehingga informasi yang didapat oleh siswa menjadi terbatas. Dengan diterapkannya pola pembelajaran tersebut, siswa hanya menjadi penerima pengetahuan yang pasif. Materi pelajaran IPS yang ada di kelas $V$ juga cukup luas untuk dipelajari, sehingga siswa mengalami kesulitan mempelajari IPS terutama pada materi perjuangan para tokoh pejuang pada masa penjajahan Belanda dan Jepang di Indonesia. Guru kelas V SD Negeri Jati 03 Pagi juga menambahkan, bahwa sumber informasi mata pelajaran IPS berasal dari teks bacaan. Namun, siswa sangat malas untuk membaca karena buku teks yang digunakan dalam pembelajaran IPS kurang menarik sehingga siswa mengalami kesulitan dalam memahami materi tersebut.

Berdasarkan latar belakang tersebut, maka fokus masalah yang diteliti yaitu: "Bahan ajar seperti apa yang tepat untuk mata pelajaran IPS topik perjuangan para tokoh pejuang pada masa penjajahan Belanda dan Jepang di Indonesia untuk siswa kelas V Sekolah Dasar?". Penelitian ini bertujuan untuk menghasilkan produk hasil pengembangan berupa bahan ajar berbasis konstruktivistik materi perjuangan para tokoh pejuang pada masa penjajahan Belanda dan Jepang di Indonesia untuk siswa kelas V Sekolah Dasar. Oleh karena itu, diharapkan dapat memberi manfaat bagi seluruh masyarakat, baik secara teoretis maupun secara praktis. Beberapa teori yang menjadi landasan dalam pengembangan bahan ajar tersebut dijelaskan sebagai berikut.

Pengembangan adalah suatu proses yang dipakai untuk mengembangkan dan memvalidasi produk pendidikan. Pengembangan dapat berupa proses, produk, dan rancangan. Dalam upaya perbaikan pendidikan, juga dilakukan berbagai macam pengembangan. Dalam hal ini, pengembangan adalah proses mengorganisasikan materi pelajaran dan pengembangan proses pembelajaran. Guru seharusnya berpartisipasi dalam pengembangan di bidang pendidikan. Produk-produk yang dibuat atau disempurnakan dalam bidang pendidikan harus sesuai dengan kebutuhan. Dalam Undang-Undang Republik Indonesia No. 18 Tahun 2002 disebutkan. Pengembangan adalah kegiatan ilmu pengetahuan dan teknologi yang bertujuan memanfaatkan kaidah dan teori ilmu pengetahuan yang telah terbukti kebenarannya untuk meningkatkan fungsi, manfaat, dan aplikasi ilmu pengetahuan dan teknologi yang telah ada, atau menghasilkan teknologi baru. Kawasan pengembangan mencakup perkembangan teknologi cetak, teknologi audiovisual, teknologi berbasis komputer dan media-media yang disajikan dalam gambar (Warsita, 2008).

Dalam penelitian ini, pengembangan yang dimaksud adalah berupa bahan ajar. Bahan ajar merupakan unsur yang penting diperhatikan oleh guru. Melalui bahan ajar tersebut, siswa dapat mempelajari hal-hal yang diperlukan untuk mencapai tujuan belajar. Bahan Ajar atau material atau sumber belajar yang mengandung substansi kemampuan tertentu yang akan dicapai oleh siswa. Secara garis besar, bahan ajar atau materi pembelajaran (instructional material) mencakup pengetahuan, keterampilan, dan sikap yang dipelajari siswa dalam rangka mencapai kompetensi yang telah ditetapkan (Dikmenum, 2003). Bahan ajar yang baik menurut Hamdani adalah bahan ajar yang segala bentuk bahan atau materi disusun secara sistematis yang digunakan untuk membantu guru atau instruktur dalam melaksanakan kegiatan belajar mengajar sehingga tercipta lingkungan atau suasana yang memungkinkan siswa untuk belajar. Masih menurut Hamdani, bahan ajar atau materi pembelajaran (instructional materials) secara garis besar terdiri atas pengetahuan, sikap yang harus dipelajari siswa dalam mencapai standar kompetensi yang telah ditentukan. Namun, ketercapaian pembelajaran juga tidak lepas dari peran guru dalam proses pembelajaran. Dalam hal ini, guru membutuhkan bahan ajar agar tujuan 
belajar dapat tercapai dengan baik.

Pendapat lain mengungkapkan bahwa bahan ajar adalah informasi, alat, dan teks yang diperlukan guru atau instruktur untuk perencanaan dan penelaahan implementasi pembelajaran (Prastowo, 2011). Bahan ajar yang dijadikan guru sebagai pedoman dalam mengajar terdiri atas beberapa jenis bentuk penyajian. Bahan ajar merupakan segala bahan (baik informasi, alat, maupun teks) yang disusun secara sistematis, yang menampilkan sosok utuh dari kompetensi yang akan dikuasai peserta didik dan digunakan dalam proses pembelajaran dengan tujuan perencanaan dan penelaahan implementasi pembelajaran.

IPS merupakan salah satu bidang studi yang dipelajari mulai dari tingkat sekolah dasar hingga pendidikan yang lebih tinggi. Tujuan bidang studi ini yaitu membina masyarakat agar mampu menyerasikan kehidupannya dengan kehidupan sosial, dan mampu memecahkan masalah-masalah sosial yang dihadapinya. Berdasarkan Permendiknas No. 22 Tahun 2006, dijelaskan bahwa IPS mengkaji seperangkat peristiwa, konsep, dan generalisasi yang berkaitan dengan isu sosial. Menurut Trianto, IPS mempelajari dan mengkaji masalah sosial, selain itu IPS juga membahas hubungan antara manusia dengan lingkungannya. Menurut Ahmadi, IPS merupakan mata pelajaran yang mempelajari kehidupan sosial yang kajiannya mengintegrasikan bidang-bidang ilmu sosial dan humaniora. Sejalan dengan pendapat tersebut, Ilmu Pengetahuan Sosial (IPS) merupakan salah satu mata pelajaran yang diberikan dari tingkat SD/MI/SDLB sampai MTs/SMPLB. Berikut adalah definisi lain dari IPS menurut Trianto, Ilmu Pengetahuan Sosial (IPS) merupakan integrasi dari berbagai cabang ilmu-ilmu sosial seperti: sosiologi, sejarah, geografi, ekonomi. Apapun bentuk pengintegrasian ilmu-ilmu sosial di sekolah, IPS di sekolah dasar memiliki misi penting yaitu membangun masyarakat dan negara. IPS bukan semata-mata penyederhaan ilmu-ilmu sosial tetapi memiliki nilai untuk menyiapkan peserta didik menghadapi kehidupan dengan segala tantangannya.

Dalam pembelajaran, guru perlu memotivasi siswa agar dapat menemukan konsep, dan mengaplikasikan konsep tersebut dalam pembelajaran, sehingga dapat bermanfaat bagi diri siswa kelak. Hal tersebut sesuai dengan teori konstruktivisme menurut Rusman yang menganggap bahwa manusia mampu mengkonstruk atau membangun setelah ia berinteraksi dengan lingkungannya. Dalam lingkungan yang sama, pengetahuan-pengetahuannya secara berbedabeda tergantung dari pengalaman masing-masing sebelumnya.

Pembelajaran konstruktivistik menurut Yamin adalah membangunkan pengetahuan melalui pengalaman, interaksi sosial, dan dunia nyata. Pengetahuan bukan seperti benda yang mudah dimuatkan dalam wadahnya. Sejalan dengan pendapat tersebut, Piaget mengemukakan bahwa pengetahuan merupakan ciptaan manusia yang dikonstruksikan dari pengalamannya, proses pembentukan berjalan terus menerus dan setiap kali terjadi rekonstruksi karena adanya pemahaman yang baru. Lebih jauh lagi, Piaget mengemukakan bahwa pengetahuan dibangun oleh pikiran anak melalui asimilasi dan akomodasi.

Pannen dalam Mustafa dan Sekar Winahyu mengemukakan bahwa dalam perkembangan pengetahuan seseorang, ada yang mengalami perubahan besar yang berkenaan dengan perubahan konsep lama melalui akomodasi, ada pula yang hanya mengembangkan atau memperluas konsep yang sudah ada melalui proses asimilasi. Konstruktivistik menurut Vygotsky memandang bahwa pengetahuan dikonstruksi secara kolaboratif antarindividual dan keadaan tersebut dapat disesuaikan oleh individu. Dengan kata lain, pembelajaran konstruktivistik merupakan pembelajaran yang berpusat pada peserta didik (student oriented), guru sebagai mediator, fasilitator, dan sumber belajar (Yamin, 2012).

Menurut Trianto, teori konstruktivis menyatakan bahwa siswa harus menemukan sendiri dan mentransformasikan informasi kompleks, mengecek informasi baru dengan aturan-aturan lama dan merevisinya apabila aturan-aturan itu tidak lagi sesuai. Menurut Jauhar, dalam belajar yang terpenting dalam teori konstruktivistik adalah proses pembelajaran siswa yang harus mendapatkan penekanan. Siswa harus aktif mengembangkan pengetahuan mereka, bukannya guru atau orang lain. Siswa harus bertanggung jawab terhadap hasil belajarnya, sehingga penekanan terhadap belajar siswa secara aktif perlu dikembangkan.

\section{METODE PENELITIAN}

Metode penelitian yang digunakan dalam penelitian ini adalah metode penelitian pengembangan (Research and Development). Teknik analisis data yang digunakan adalah statistik deskriptif kuantitatif, yaitu statistik yang digunakan untuk menganalisis data dengan cara menggambarkan data yang telah 
terkumpul sebagaimana adanya tanpa ada maksud membuat kesimpulan yang bersifat umum atau generalisasi. Evaluasi data yang digunakan dalam pengembangan ini yakni evaluasi formatif. Tahap evaluasi formatif meliputi empat tahap yakni (a) evaluasi satu-satu oleh para ahli (one to one evaluation by experts), (b) evaluasi satu-satu oleh peserta didik (one to one evaluation by learners), (c) evaluasi kelompok kecil (small group evaluation), dan (d) uji coba lapangan (field tryout atau field testing). Penelitian ini dilakukan di kelas V sekolah dasar yaitu di SDN Jati 03 Pagi Jakarta Timur. Penelitian pengembangan ini dilaksanakan pada semester dua tahun ajaran 2015/2016, pada bulan Oktober 2015 sampai Juni 2016.

\section{HASIL DAN PEMBAHASAN}

Nama produk dari hasil pengembangan ini adalah bahan ajar IPS berbasis konstruktivistik pada materi perjuangan melawan penjajah kelas V SD. Bahan ajar ini menguraikan Kompetensi Dasar (KD) 2.1 yaitu mendeskripsikan perjuangan para tokoh pejuang pada masa penjajahan Belanda dan Jepang. Bahan ajar yang dimaksud adalah produk cetak yang didesain sesuai dengan karakteristik penggunanya yaitu untuk siswa kelas V sekolah dasar. Produk ini berisi materi pembelajaran IPS tentang perjuangan melawan penjajah, yang berbasis konstruktivistik dan mencakup Standar Kompetensi serta Kompetensi Dasar kelas V semester 2 berdasarkan KTSP 2006. Adapun hasil penelitian yang didapat sebagai berikut. Penilaian ketiga ahli berdasarkan instrumen yang digunakan dengan rekapitulasi ahli materi tersaji pada tabel 1.

Tabel 1. Hasil Rekapitulasi Ahli Materi

\begin{tabular}{llcccc}
\hline No. & Aspek yang dinilai & $\begin{array}{c}\text { Jumlah } \\
\text { Butir }\end{array}$ & $\begin{array}{c}\text { Skor } \\
\text { Kriterium }\end{array}$ & $\begin{array}{c}\text { Jumlah } \\
\text { Nilai }\end{array}$ & $\%$ \\
\hline 1. & $\begin{array}{l}\text { Kesesuaian uraian } \\
\text { materi dengan SK } \\
\text { dan KD }\end{array}$ & 11 & 44 & 38 & \\
2. & Keakuratan materi & 7 & 28 & 24 & \\
3. & $\begin{array}{l}\text { Materi pendukung } \\
\text { pembelajaran }\end{array}$ & 12 & 48 & 43 & \\
4. & Konstruktivistik & 6 & 24 & 21 & \\
\hline & $\quad$ Jumlah & 36 & 144 & 126 & 86,89 \\
\hline
\end{tabular}

Dapat dilihat pada tabel 1 di atas, bahan ajar berbasis konstruktivistik materi perjuangan para tokoh pejuang pada masa penjajahan Jepang dan Belanda yang dilakukan oleh ahli materi didapatkan rata-rata kelayakan produk sebesar 86,89\% dan dikategorikan sangat baik. Selanjutnya, untuk hasil rekapitulasi ahli media tersaji pada Tabel 2.

Tabel 2. Hasil Rekapitulasi Ahli Media

\begin{tabular}{llcccc}
\hline No. & Aspek yang dinilai & $\begin{array}{c}\text { Jumlah } \\
\text { Butir }\end{array}$ & $\begin{array}{c}\text { Skor } \\
\text { Kriterium }\end{array}$ & $\begin{array}{c}\text { Jumlah } \\
\text { Nilai }\end{array}$ & $\%$ \\
\hline 1. & Teknik penyajian & 8 & 32 & 31 & \\
2. & $\begin{array}{l}\text { Penyajian } \\
\text { pembelajaran }\end{array}$ & 5 & 20 & 19 & \\
3. & Kelengkapan & 8 & 32 & 31 & \\
& penyajian & & & & \\
4. & Ukuran buku & 2 & 8 & 8 & \\
5. & Desain kulit buku & 7 & 28 & 27 & \\
6. & Desain isi buku & 16 & 64 & 63 & \\
7. & Ilustrasi isi & 4 & 16 & 16 & \\
\hline & $\quad$ Jumlah & 50 & 200 & 195 & 97,5 \\
\hline
\end{tabular}

Dapat dilihat pada tabel 2 di atas, bahan ajar berbasis konstruktivistik materi perjuangan para tokoh pejuang pada masa penjajahan Jepang dan Belanda yang dilakukan oleh ahli media didapatkan rata-rata kelayakan produk sebesar 97,5\% dan dikategorikan sangat baik. Untuk hasil rekapitulasi ahli bahasa tersaji pada Tabel 3 .

Tabel 3. Hasil Rekapitulasi Ahli Bahasa

\begin{tabular}{llcccc}
\hline No. & Aspek yang dinilai & $\begin{array}{c}\text { Jumlah } \\
\text { Butir }\end{array}$ & $\begin{array}{c}\text { Skor } \\
\text { Kriterium }\end{array}$ & $\begin{array}{c}\text { Jumlah } \\
\text { Nilai }\end{array}$ & $\%$ \\
\hline 1. & $\begin{array}{l}\text { Kesesuaian } \\
\text { dengan tingkat } \\
\text { perkembangan } \\
\text { siswa }\end{array}$ & 2 & 8 & 8 & \\
2. & Kekomunikativan & 4 & 16 & 15 & \\
3. & $\begin{array}{l}\text { Keruntutan dan } \\
\text { keterpaduan alur } \\
\text { pikir }\end{array}$ & 4 & 16 & 15 & \\
4. & $\begin{array}{l}\text { Penggunaan } \\
\text { kalimat }\end{array}$ & 2 & 8 & 7 & \\
\hline & $\quad$ Jumlah & 12 & 48 & 45 & 93,75 \\
\hline
\end{tabular}

Dapat dilihat pada tabel 3 di atas, bahan ajar berbasis konstruktivistik materi perjuangan para tokoh pejuang pada masa penjajahan Jepang dan Belanda yang dilakukan oleh ahli bahasa didapatkan rata-rata kelayakan produk sebesar 93,75\% dan dikategorikan sangat baik.

Setelah draf produk mendapatkan komentar dan saran dari para ahli, peneliti memperbaiki beberapa bagian yang mendapatkan komentar maupun saran dari para ahli. Setelah melalui tahap valiadasi ahli, tahap berikutnya pengembang melakukan evaluasi formatif produk pada pengguna produk. Tabel 4 berikut adalah hasil analisis rekapitulasi one to one evaluation

Tabel 4. Hasil Rekapitulasi One To One Evaluation 


\begin{tabular}{ccc}
\hline No & Responden & Persentase (\%) \\
\hline 1 & AZ & 93,75 \\
2 & MA & 93,75 \\
3 & MF & 100 \\
\hline & Rata-rata & 95,83 \\
\hline
\end{tabular}

Berdasarkan hasil rekapitulasi evaluasi formatif one to one, maka kualitas produk bahan ajar berbasis konstruktivistik materi perjuangan para tokoh pada masa penjajahan Belanda dan Jepang menurut tiga responden dengan kemampuan yang berbeda (kelompok tinggi, sedang, dan rendah) mendapat skor rata-rata 95,83\% dengan kriteria sangat baik.

Evaluasi formatif kelompok kecil (small group) yang dilakukan terhadap sepuluh orang responden tersebut, menghasilkan rekapitulasi pada Tabel 5 sebagai berikut.

Tabel 5. Hasil Rekapitulasi Uji Coba Kelompok Kecil (Small Group)

\begin{tabular}{ccc}
\hline No & Responden & Persentase $(\%)$ \\
\hline 1. & AWD & 84,61 \\
2. & DLA & 100 \\
3. & DAK & 100 \\
4. & H & 84,61 \\
5. & HAI & 84,61 \\
6. & IHH & 84,61 \\
7. & LO & 92,3 \\
8. & NAO & 92,3 \\
9. & RI & 100 \\
10. & ST & 100 \\
\hline \multicolumn{3}{c}{ Rata-rata }
\end{tabular}

Berdasarkan hasil analisis rekapitulasi uji pelaksanaan lapangan, maka kualitas produk bahan ajar berbasis konstruktivistik materi perjuangan para tokoh pada masa penjajahan Belanda dan Jepang menurut tiga puluh responden mendapat skor ratarata $97,71 \%$ dengan kriteria sangat baik.

\section{PENUTUP}

\section{Kesimpulan}

Peneliti mengembangkan bahan ajar IPS berbasis konstruktivistik mengacu pada model pengembangan Atwi Suparman. Pada pengembangan ini, bahan ajar diujikan kepada tiga orang ahli yang terdiri atas ahli media, ahli materi, dan ahli bahasa yang berasal dari kalangan dosen. Hasil rata-rata persentase penilaian dari expert review secara keseluruhan terhadap bahan ajar IPS berbasis konstruktivistik mencapai 97,5\% dan dapat dikategorikan sangat baik. Uji coba one to one yang dilaksanakan di SDN Jati 03 Pagi Jakarta Timur didapatkan hasil rata-rata persentase penilaian dari tiga responden mencapai 95,83\% dan dikategorikan sangat baik. Kemudian uji coba kelompok kecil (small group) dilaksanakan di SD yang sama yaitu SDN Jati 03 Pagi, didapatkan hasil rata-rata persentase penilaian dari sepuluh orang responden yakni sebesar $92,3 \%$ dan dapat dikategorikan sangat baik. Selanjutnya, tahap terakhir yaitu uji pelaksanaan lapangan (field test) yang dilakukan diSDN Jati 03 Pagi Jakarta Timur didapatkan hasil rata-rata persentase penilaian dari tiga puluh orang responden mencapai 97,71\% dan dikategorikan sangat baik. Berdasarkan hasil analisis uji expert review, uji coba one to one, small group, dan uji pelaksanaan lapangan (field test) dapat disimpulkan bahwa produk yang dikembangkan berupa "Bahan Ajar IPS Berbasis Konstruktivistik Kelas VSD" merupakan produk yang valid dan dapat digunakan sebagai alternatif bahan ajar di sekolah.

\section{Saran}

Berdasarkan kesimpulan di atas, maka penelitian ini memiliki beberapa saran. Pertama, siswa diharapkan menggunakan bahan ajar IPS berbasis konstruktivistik pada materi perjuangan para tokoh dalam melawan penjajah pada masa penjajahan Belanda dan Jepang sebagai sumber belajar agar pembelajaran menjadi lebih efektif, siswa menjadi lebih kreatif, dan mandiri dalam belajar.

Kedua, saran untuk pihak guru. Guru diharapkan dapat menggunakan bahan ajar IPS berbasis konstruktivistik pada materi perjuangan tokoh dalam melawan penjajah pada masa penjajahan Belanda dan Jepang sebagai bahan ajar alternatif untuk memberikan pemahaman mengenai perjuangam melawan penjajah

Ketiga, saran untuk pihak sekolah. Sekolah diharapkan dapat menggunakan bahan ajar IPS berbasis konstruktivistik pada materi perjuangan tokoh dalam melawan penjajah pada masa penjajahan Belanda dan Jepang sebagai referensi bahan ajar dan koleksi bahan ajar di sekolah.

Keempat, untuk peneliti selanjutnya diharapkan dapat menghasilkan produk yang lebih baik, serta dapat mengatur waktu penelitian dengan baik agar dapat memperoleh hasil yang terbaik pada saat melakukan penelitian.

\section{DAFTAR PUSTAKA}

Amri, S.,\& Ahmadi, I. K. (2011). Mengembangkan pembelajaran ips terpadu. Jakarta: Prestasi Pustakaraya. 
Aunurrahman. (2011). Belajar dan pembelajaran. Bandung: Alfabeta.

Badan Standar Nasional Pendidikan (BSNP). (2011). Standar kompetensi dan kompetensi dasar kelas $V$ sekolah dasar/madrasah ibtidaiyah. Jakarta: Kementerian Pendidikan Nasional.

Baharudin, \& Wahyuni, E. N. (2011). Teori belajar dan pembelajaran. Yogyakarta: Ar-Ruzz Media.

Emzir. (2014). Metodologi penelitian pendidikan. Jakarta: Raja Grafindo Persada.

Hamdani. (2011). Strategi belajar mengajar. Bandung: Pustaka Setia.

Hindarto, M. P. (2006). Desain warna interior. Yogyakarta: Media Pressindo.

Hurlock, E. B. (1978). Perkembangan anak. Jakarta: Erlangga.

Jauhar, M. (2011). Implementasi PAIKEM dari behavioristik sampai konstruktivistik. Jakarta: Prestasi Pustakaraya.

Muslich, M. (2010). Text book writing. Jogjakarta: Arruzz Media.

Putra, N. (2011). Research and development. Jakarta: Raja Grafindo Persada.

Prastowo, A. (2013). Pengembangan bahan ajar tematik. Yogyakarta: DIVA Press.

Prastowo, A. (2011). Panduan kreatifmembuat bahan ajar inovatif. Yogyakarta: DIVA Press.

Rusman. (2012). Belajar dan pembelajaran berbasis komputer. Bandung: Alfabeta.

Santrock, J. W. (2009). Psikologi pendidikan educational psychology. Jakarta: Salemba Humanika.

Setyosari, P. (2013). Metode penelitian pendidikan dan pengembangan. Jakarta: Kencana Prenada Media Group.

Siregar, E.,\& Nara, H. (2010). Belajar dan pembelajaran. Bogor: Ghalia Indonesia.
Sitepu, B. P. (2012). Penulisan buku teks pelajaran. Bandung: Remaja Rosdakarya.

Smith, M. K., dkk. (2009). Teori pembelajaran dan pengajaran. Jogjakarta: Mirza Media Pustaka.

Sugiyono. (2011). Metode penelitian kuantitatifkualitatif dan RED. Bandung: Alfabeta.

Sukmadinata, N. S. (2011). Landasan psikologi proses pendidikan. Bandung: PT Remaja Rosdakarya.

Sunarto,\& Hartono, A. (2008). Perkembangan peserta didik. Jakarta: Rineka Cipta.

Suparman, M. A. (2012). Desain instruksional modern. Jakarta: Erlangga.

Suparno, P. (1997). Filsafat konstruktivisme dalam pendidikan. Yogyakarta: Kanisius.

Trianto. (2009). Mendesain pembelajaran inovatif-progresif. Jakarta: Kencana Prenada Media Group.

Trianto. (2010). Model pembelajaran terpadu konsep, strategi, dan implementasinya dalam KTSP. Jakarta: Bumi Aksara.

Trianto. (2007). Model pembelajaran terpadu dalam teori dan praktek. Jakarta: Prestasi Pustaka.

Trianto. (2010). Model pembelajaran terpadu. Jakarta: Bumi Aksara.

Wardoyo, S. M. (2013). Pembelajaran konstruktivisme. Bandung: Alfabeta.

Warsita, B. (2008). Teknologi pembelajaran landasan dan aplikasinya. Jakarta:Rineka Cipta.

Wiyani, N. A. (2013). Desain pembelajaran pendidikan. Yogyakarta: Ar-Ruzz Media.

Yamin, M. (2010). Desain pembelajaran berbasis satuan pendidikan. Jakarta: Gaung Persada Press.

Yamin, M. (2012). Desain baru pembelajaran konstruktivistik. Jakarta: Referensi.

Yani, A. (2009). Pembelajaran IPS. Jakarta: Direktorat Jenderal Pendidikan Islam Departemen Agama Republik Indonesia. 